\title{
FORECASTING MUNICIPAL WASTE TREATMENT EFFLUENT AND COSTS: AN APPLICATION TO THE CHESAPEAKE BAY
}

\author{
Virginia D. McConnell, John H. Cumberland, Patrice Gordon*
}

\section{Introduction}

The treatment of pollution at wastewater treatment facilities is an issue of growing concern for the health of large estuaries such as the Chesapeake Bay. Increasingly, hard choices will have to be made about how and where pollutant loadings can be reduced and at what cost. In the model presented here, we develop a way of forecasting future effluent levels for publicly owned waste treatment works (POTWs) from residential sources under a variety of possible development and treatment scenarios for river basins of the Chesapeake Bay. The model also allows us to compare the average costs of removal of several pollutants for the various basins.

The Chesapeake Bay has been described as "an ecosystem in decline," 1 suffering from high loadings of both degradable pollutants, as measured by Biological Oxygen Demand (BOD) and suspended solids, ${ }^{2}$ and nutrients such as phosphorus and nitrogen. The latter pollution problem, that of excessive nutrients, will be the most critical problem for the Bay in the years ahead, and is also one of the most costly to manage. Nutrient loads come from both point sources (such as waste treatment facility effluent), and from non-point sources (such as agricultural run-off). ${ }^{3}$ Here we focus only on the phosphorus effluent from POTWs. ${ }^{4}$

Pollutant effluent from POTWs will vary over time depending on population growth, sewer development, and the type and degree of treatment at each facility. Population forecasts must be linked to the type of treatment over some geographic region; we use river basins of the Chesapeake Bay for the application presented here. The costs of various treatment levels from POTWs are also derived and

\footnotetext{
* McConnell is in the Department of Economics, University of Maryland, Baltimore County, and Curnberland and Gordon are in the Bureau of Business and Economic Reseanch, and Department of Economics, University of Maryland, College Park, Maryland. The computer time for this project was supported in full through the facilities of the Computer Science Center of the University of Maryland, College Park, Maryland.
}

compared by basin.

In the following section of the paper, we present the method for forecasting residential pollutant loadings from POTWs and the associated costs. In the next section, we use this method to forecast emissions of three pollutants in the Chesapeake Bay region. We examine the impact of different regulations and land-use options on pollutant loadings in the seven major River Basins of the Bay. In the last section we summarize the results.

\section{Method for Forecasting Emissions from Municipal Waste Treatment Plants}

In this section we develop a method of forecasting regional emissions for three pollutants, Biological Oxygen Demand (BOD), Suspended Solids (SS), and Phosphorus. To examine the effects over time of various management techniques to reduce water pollution from residential POTWs, we need to link a number of key variables. Population changes must be forecast over time and linked to gross pollution levels for the various pollutants. Gross pollution into the plants must then be linked to net effluent of pollutants into the receiving water body. Each of these links is discussed below.

Population forecasts by county are available from a number of sources. The population forecasts used here for the Chesapeake Bay are from the Multiregional, Multi-Industry Forecasting Model (MRMI) developed by Curtis C. Harris at the University of Maryland (Harris, (1980). In the MRMI model, population movement over time is a function of an economic model of industry movement. ${ }^{6}$

Given a set of population forecasts, we want to determine gross pollution from residential sources at POTWs, for each of the three pollutants. We will do the analysis using river basins as the relevant regional aggregation. We first calculate per capita pollution coefficients by river basin using plant level data on influent concentrations and population served. The principle source of these data is the 1982 
E.P.A. Needs Survey (U.S. E.P.A., 1982). It provides POTW plant level data for all of the plants in the Chesapeake Bay region. Taking only those plants which serve residential customers and which report positive levels of the pollutants under consideration, we estimate gross influent of pollutant $q$ at plant $j$ as a function of the residents served by facility $j$ and of non-residents served by facility $j$ :

$$
\mathbf{Q}_{\mathrm{qj}}=\alpha \mathrm{RT}_{\mathrm{j}}+\beta \mathrm{NRT}_{\mathrm{j}}+\mathrm{e}
$$

where: $\quad Q_{q j}=$ gross influent of pollutant $q$ at plant j

$$
\begin{aligned}
\mathrm{RT}_{\mathrm{j}} & =\text { residents served by plant } \mathrm{j} \\
\mathrm{NRT}_{\mathrm{j}} & =\text { non-residents served by plant } \mathrm{j}
\end{aligned}
$$

Non-residents, NRT, could be, for example, tourists or commuters who use facilities in the plants' region but do not reside in that region.

Equation (1) is estimated by basin for each pollutant using 1981 data from the Needs Survey. The resulting regional gross residual coefficients $(\alpha, \beta)$ represent kilograms of pollutant q per person per day in $1981 .^{6}$ These coefficents can remain constant over time, or they may change for a number of reasons. For example, if households cut back on the use of phosphate detergents, the coefficient relating population to gross phosphorus pollution would fall. We show results for this case in the analysis below.

We use these coefficients along with population forecasts to forecast gross emissions by basin for each of the pollutants. Total gross emissions in any forecast year, $t$, can be estimated using equation (2) below, where Prt is population forecast in year $t$ for basin $r:^{?}$

$$
\mathbf{Q}_{q}^{r t}=\alpha_{q}^{r t} \quad\left(P^{r t} \quad \varphi^{r t}\right) \epsilon_{q}^{r t}
$$

where (3a): $\varphi^{\mathrm{rt}}=\sum_{j=1}^{n} \frac{\mathrm{F}_{\mathrm{j}}^{\mathrm{rt}}}{\mathrm{F}^{\mathrm{rt}}}\left(\frac{\mathrm{RT}_{\mathrm{j}}^{\mathrm{rt}}}{\left(\mathrm{RT}_{\mathrm{j}}^{\mathrm{rt}}+\mathrm{NT}_{\mathrm{j}}^{\mathrm{rt}}\right)}\right)$,

$$
\text { (3b) } \epsilon \underset{q}{\mathrm{rt}}=1+\frac{\beta_{\mathrm{q}}^{\mathrm{r}}}{\alpha_{\mathrm{q}}^{\mathrm{r}}}\left(\frac{\mathrm{NRT}^{\mathrm{rt}}}{\mathrm{RT}^{\mathrm{rt}}}\right) \text {, }
$$

$$
\begin{aligned}
& \text { and: } \quad \frac{\partial Q_{\mathrm{q}}^{\mathrm{rt}}}{\partial \alpha_{\mathrm{q}}^{\mathrm{rt}}}>0, \quad \frac{\partial \mathbf{Q}_{\mathrm{q}}^{\mathrm{rt}}}{\partial \mathrm{P}^{\mathrm{rt}}}>0 \text {, } \\
& \frac{\partial \mathbf{Q}_{\mathrm{q}}^{\mathrm{rt}}}{\partial \varphi}>0, \frac{\partial \mathbf{Q}^{\mathrm{rt}}}{\partial \epsilon}>0 \text {. } \\
& \mathbf{q}=\text { pollutant } \\
& \mathrm{n}=\text { number of plants in basin } \mathrm{r} \text { at time } \mathrm{t} \\
& \mathrm{RT}=\text { residents of region receiving treat- } \\
& \text { ment at facility } j \\
& \mathrm{NT}=\underset{\text { residents of }}{\text { treatment }} \text { region not receiving } \\
& F=\text { volume of flow from plant } j \text {, in } \\
& \text { millions of gallons/day. }
\end{aligned}
$$

The two scaling parameters, $\varphi$ and $\epsilon$, need further explanation. $\epsilon$ represents a scaling factor which allows for the adjustment of total gross residuals in areas where non-residents form a significant portion of the population served, as allowed for by equation (1) above. $\varphi$ is a population adjustment factor, which adjusts the total change in basin population to account for that portion served by treatment plants. Septic tank users are an example of residents who do not receive treatment from municipal facilities. ${ }^{8}$ Data from the Needs Survey make it clear that $\varphi$ changes over time; the percentage of total population served by sewers increases significantly between 1981 and 2000 for all plants. Equation (3a) allows us to determine a basin adjustment coefficient, where each plant's proportion of population served is weighted by volume of flow, Frt. This coefficient can be changed with alternative assumptions about sewered versus nonsewered development in the future.

To reduce pollution levels at the facility, POTWs use varying levels of treatment for the major pollutants under consideration hereBOD, suspended solids, and phosphorus. Pollution reduction can be measured either in terms of final effluent concentration or in terms of percentage removal of the pollutant. We define the treatment efficiency of a particular process for cleaning up pollutant $q$ at a 
plant using a percentage removal definition:

(4) $\mathrm{TE}_{\mathrm{q}}=1-\frac{\text { outflow concentrations }}{\text { inflow concentrations }}$

The Needs Survey provides data on outflow and inflow concentrations for each plant for 1981 and 2000 based on current federal regulations for future treatment. The Survey also defines 61 different treatment processes. However, the various combinations of technologies employed by a particular plant place it in one of eight general treatment categories:

(1) Primary-preliminary treatment such as comminution, screening, grit chambers, primary sedimentation, etc., and in some cases, chlorination.

(2) Advanced primary-includes lagoon systems and trickling filter plants; has greater removal efficiencies for BOD and SS than primary plants.

(3) Secondary-includes most biological processes such as trickling filters, activated sludge (including oxidation ditches), etc., with no additional treatment except disinfection (minimum of $\mathbf{8 5}$ percent of BOD).

(4) Secondary with nutrient removal-same as (3) above, but with removal of nutrients.

(5) Advanced secondary-treatment plants in this category are classified as such primarily on effluent BOD and SS and concentrations; higher removal efficiencies than secondary.

(6) Advanced secondary with nutrient removal-same as (5) but with removal of nutrients.

(7) Advanced Wastewater Treatmenttreatment level higher than advanced secondary.

(8) Advanced Wastewater Treatment with nutrient removal-same as (7), but with nutrient removal.

In general, primary, advanced primary, secondary, advanced secondary, and advanced wastewater treatment are processes designed to remove successively greater amounts of BOD and Suspended Solids. The nutrient removal categories add removal of phosphorus to the treatment of the other two pollutants. ${ }^{9}$ We develop general measures of treatment efficiency by pollutant for each of the plant treatment types.
For forecasting with basin population data, basin treatment levels must be developed. A weighted average treatment efficiency by basin for each pollutant is developed, where the weights are based on the flow at each facility in the area:

(5) $T E_{i q}^{r t}=\sum_{j=1} \frac{\sum_{i j}^{r t} T E_{i q j}^{r t}}{\sum_{j=1}^{n} F_{i j}^{r t}}$

where $i$ is treatment category, and $n$ is the number of plants in the river basin of category i. Plant level treatment efficiencies can be forecast from the Needs Survey or from alternative assumptions about future pollution reduction requirements. Basin treatment efficiencies for each pollutant can be determined as a flow weighted average across all treatment categories.

(6) $\mathrm{TE}_{\mathrm{q}}^{\mathrm{rt}}=\sum_{\mathrm{i}=1}^{8} \frac{\sum_{\mathrm{j}}^{\Sigma} \mathrm{F}_{\mathrm{ij}}^{\mathrm{rt}}}{\mathrm{F}^{\mathrm{rt}}} \mathrm{TE}_{\mathrm{iq}}^{\mathrm{rt}}$ where $F=$ total flow and $i=$ treatment category ( 1 to 8 ). River basin treatment efficiencies, $\mathrm{TE}_{\mathrm{q}}^{\mathrm{r}}$, thus reflect the character and relative importance of the treatment technologies (and corresponding removal efficiencies) employed in each basin. Different assumptions will be made below about the legal requirements for treatment.

The final step is the application of the basin specific treatment efficiencies to the gross emissions determined in equation (2), to get effluent levels, $R$, for each pollutant $q$.

(7) $\mathrm{R}_{\mathrm{q}}^{\mathrm{rt}}=\mathrm{Q}_{\mathrm{q}}^{\mathrm{rt}}\left(1-\mathrm{TE}_{\mathrm{q}}^{\mathrm{rt}}\right)$

Equation (7) produces the effluent level of each pollutant in terms of kilograms per day. Substituting equation (2) into (7) yields an equation for the net regional effluent by pollutant for residential POTWs:

(8) $\begin{aligned} \mathrm{R}_{\mathrm{q}}^{\mathrm{rt}}= & \left(\alpha_{\mathrm{q}}^{\mathrm{rt}}\left(\mathrm{P}^{\mathrm{rt}} \varphi^{\mathrm{rt}}\right) \epsilon \underset{\mathrm{q}}{\mathrm{rt}}\right) \cdot \\ & \left(1-\mathrm{TE}_{\mathrm{q}}^{\mathrm{rt}}\right)\end{aligned}$

All of the right-hand side values can vary over 
time, and hence affect net effluent, $R_{q}^{r t}$. The percentage change in $\mathrm{R}_{\mathrm{q}}^{\text {rt }}$ can, using a growth accounting equation, be broken into its component parts:

(9) $\% \Delta \mathrm{R}_{\mathrm{q}}^{\mathrm{r}}=\% \Delta \alpha_{\mathrm{q}}^{\mathrm{r}}+\% \Delta \varphi^{\mathrm{r}}+\% \Delta \epsilon_{\mathrm{q}}^{\mathrm{r}}+\% \Delta \mathrm{P}^{\mathrm{r}}$

$$
-\left(1-\mathrm{TE}_{\mathrm{q}}^{\mathrm{r}}\right) \% \Delta \mathrm{TE}_{\mathrm{q}}^{\mathrm{r}}
$$

The percent change in $\mathrm{R}_{\mathrm{q}}^{\mathrm{r}}$ observed over time will depend on the rates of change in all of the right-hand side variables. Holding net effluent, $R_{q}^{r}$, constant over time, we can solve for the trade off between population growth, $\mathrm{P}^{\mathrm{r}}$, and treatment efficiency in pollutant q:

$$
\frac{\% \Delta \mathrm{TE}_{\mathrm{q}}^{\mathrm{r}}}{\% \Delta \mathrm{P}^{\mathrm{r}}}=\frac{1}{1-\mathrm{TE}_{\mathrm{q}}^{\mathrm{r}}}
$$

As population grows over time at some constant rate, the treatment efficiency of POTWs must grow at a multiple of that growth rate.

Equation (9) can also be useful for determining how serious forecasting errors are in the determinants of net effluent for forecasting effluent. By taking the log of (8), we can determine the percent change in net effluent $R_{q}^{r}$ resulting from percent changes in any of the other variables. It is evident that percent changes in all right side variables except treatment efficiency, $\mathrm{TE}_{\mathrm{q}}^{\mathrm{r}}$, will cause an equal percent change in $R_{q}^{r}$. However, the effect of a percent change varies with $\mathrm{TE}_{\mathrm{q}}^{\mathrm{r}}$ in the following way:

$$
\frac{\partial 1 \mathrm{nR}_{\mathrm{q}}^{\mathrm{r}}}{\partial \ln \mathrm{TE}_{\mathrm{q}}^{\mathrm{r}}}=\frac{\mathrm{TE}_{\mathrm{q}}^{\mathrm{r}}}{\mathrm{TE}_{\mathrm{q}}^{\mathrm{r}}-1}
$$

At higher treatment levels, the effect of misforecasting $\mathrm{TE}_{\mathrm{q}}^{\mathrm{r}}$ on the net effluent can be quite high. For example, an increase in treatment efficiency of BOD from 80 to 85 percent (as might occur within the range of what is considered secondary treatment), can mean an effluent difference of 25 percent.

This finding is important for two reasons. First, an error in treatment efficiency forecasts can mean a substantial error in effluent. Thus a 1 percent error in forecasting $\mathrm{TE}_{\mathrm{q}}^{\mathrm{r}}$ is much more serious than a 1 percent error in popula- tion forecast. Also, increases in treatment efficiencies when there is a high level of treatment will reduce pollution by a multiple of that increase.

\section{Costs of Treatment}

Costs of treatment will depend on the capacity of the treatment facility, the average flow, and the type of treatment. The cost function for a facility can be defined generally:

$$
\begin{aligned}
\text { (11) } \mathrm{C}= & \mathrm{c}\left(\mathrm{TE}_{\mathrm{q}}, \mathrm{K}, \mathrm{F}, \mathrm{W}_{\mathrm{j}}\right) \\
\text { where } \mathrm{C}= & \text { total costs } \\
\mathrm{TE}_{\mathrm{q}}= & \text { treatment efficiency, for each } \\
& \text { pollutant } \mathrm{q} \\
\mathrm{K}= & \text { capacity of the facility } \\
\mathrm{F}= & \text { flow per unit time } \\
\mathrm{W}_{\mathrm{j}}= & \text { vector of input prices. }
\end{aligned}
$$

With the available data, we were not able to estimate cost functions as in equation (11), but instead we relied on engineering cost functions (see Tihansky, 1974 and U.S. EPA, 1982). The engineering equations relate cost to various types of treatment and the capacity of the facility. The cost functions have the general functional form:

$$
\mathrm{C}_{\mathrm{c}}^{\mathrm{m}}=\delta \mathrm{K}^{\mathrm{p}},
$$

where $\mathbf{C}^{\mathrm{m}}=$ total capital construction costs for treatment type $\mathrm{m}$. A similar functional form is used for operating and maintenance. The equations used for both capital construction costs and operating and maintenance costs are displayed in Appendix I. The cost equations for BOD and SS removal involve no nutrient removal. Costs for phosphorus include nutrient removal capability. All costs presented below are on an annual basis.

\section{Application to the Chesapeake Bay}

The methods described above can be used for forecasting effluent levels and costs of removal for different pollutants from POTWs into river basins of the Chesapeake Bay. The major basins we examine are shown in Figure 1 and listed in Table 1 with the associated number of plants, total flow, population and percent change in 
An Application to the Chesapeake Bay

Table 1

POTW8-Chesapeake Bay

1981

\begin{tabular}{lccrr}
\hline \hline $\begin{array}{l}\text { River } \\
\text { Basin }\end{array}$ & $\begin{array}{c}\text { No. of } \\
\text { Plants }\end{array}$ & $\begin{array}{c}\text { Total Design } \\
\text { Flow (MGD) }\end{array}$ & $\begin{array}{r}\text { Population } \\
\text { (thousands) }\end{array}$ & $\begin{array}{r}\text { \% Change in Population } \\
\text { (1981-2000) }\end{array}$ \\
\hline Potomac & 94 & 551 & 3,109 & 21.0 \\
Paturent & 13 & 49 & 559 & 9.3 \\
Patapsco & 13 & 300 & 1,735 & 28.2 \\
Chester & 13 & 3 & 40 & 25.0 \\
Eastern Shore & 31 & 31 & 190 & 17.9 \\
Susquehann & 11 & 182 & 1,389 & 7.3 \\
Lower Bay & 26 & 179 & 1,351 & 30.3 \\
\hline \hline
\end{tabular}

population between 1981 and 2000, as forecast by the MRMI model (Harris, 1980). The river basin with the largest population is the Potomac, serving the Washington, D.C. metropolitan area, with the Patapsco basin second largest, serving the Baltimore area. The Susquehanna, serving central Pennsylvania and parts of Maryland, and the Lower Bay, serving the Portsmouth and Norfolk, Virginia area, are next largest. For three of the four large river basins in the metropolitan areas, our forecasts indicate increases in population by more than 20 percent before the year 2000 , the exception being the Susquehanna.
The data on the plants existing in 1981 come from the Needs Survey data (U.S. EPA, 1982). In order to forecast to the year 2000 , we must make assumptions about the number and technology of new plants coming on line in forecast years, and the proportion of additional population they will serve. Our initial assumptions for these variables are from the Needs Survey forecasts for the year 2000, and we call this the "current plans" scenario. Table 2 illustrates basin treatment efficiencies as determined from equations (5) and (6) with data on current plans from the Needs Survey. The "current plans" scenario reflects plant by plant

Table 2

Sample Basin Treatment Efficiencies

Current Plans

1981

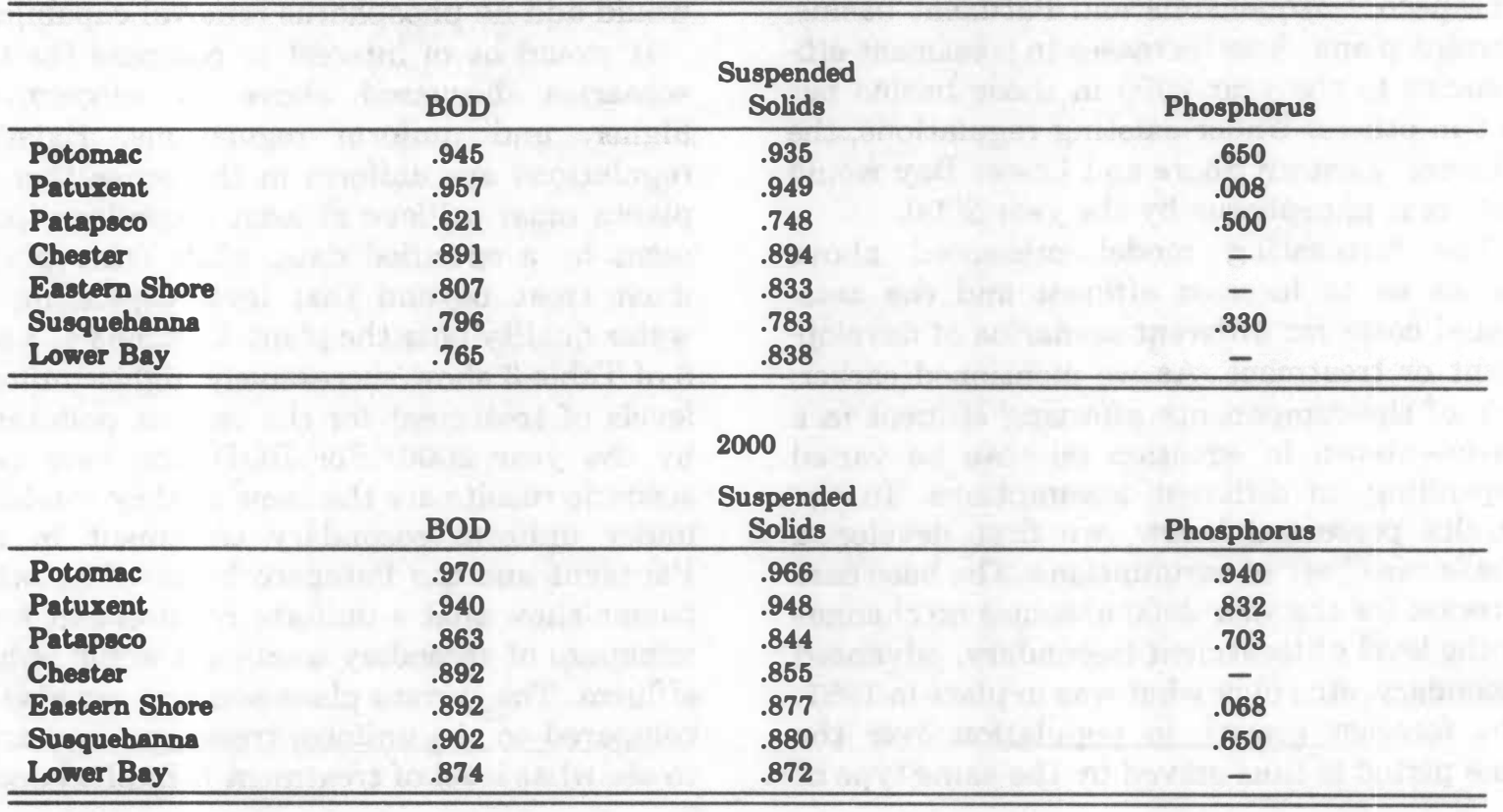


forecasts of the level of treatment which will be required under existing federal and state regulation by the year 2000 . Under the Federal Water Pollution Control Act of 1972, all municipal sewage plants were to achieve secondary treatment by 1977 , with extensions to 1983 . States will be given the authority to issue permits to POTWs under the National Pollutant Discharge Elimination System (NPDES). The secondary treatment level is defined by EPA as effluent BOD and SS concentrations of no more than 30 milligrams per liter, or 85 percent removal, whichever is the more stringent requirement. By 1981 , only 60 percent of treatment plants around the Bay had secondary treatment. By the year 2000, according to the Survey, all plants would have a minimum of secondary treatment. In addition, some plants under the NPDES permitting system would be required to treat at higher than secondary removal levels, or to reduce nutrients such as phosphorus, depending on the location of the facility as well as existing and future water quality.

Table 2 indicates that under the "current plans" scenario, increases in treatment by the year 2000 vary substantially by basin. The Patapsco, Susquehanna, and Lower Bay would have significant increases in treatment efficiency of BOD and suspended solids, while treatment in the Potomac and Patuxent basins would change very little. For phosphorus, which is a more serious problem in the northern reaches of the Bay around the Potomac, Patapsco, Susquehanna and Patuxent basins, current plans show increases in treatment efficiencies to the year 2000 in those basins but not in others. Under existing regulations, the Chester, Eastern Shore and Lower Bay would not treat phosphorus by the year 2000 .

The forecasting model presented above allows us to forecast effluent and the associated costs for different scenarios of development or treatment. As we mentioned earlier, any of the components affecting effluent in a basin-shown in equation (8)-can be varied depending on different assumptions. In the results presented below, we first develop a "base case" set of assumptions. The base case forecast for the year 2000 assumes no changes in the level of treatment (secondary, advanced secondary, etc.) over what was in place in 1981. The forecast growth in population over the time period is thus served by the same type of treatment in place at the beginning of the period. Table 3 shows the net effluent levels for BOD and suspended solids for the Base Case in the first two columns. Column one of Table 3 shows net effluent in 1981, and column 2 shows the percent change in effluent with no further treatment by the year 2000 for each of the three pollutants. In all basins, BOD effluent increases, by a maximum of 36 percent in the Potomac, and a minimum of 11 percent in the Susquehanna. These increases in effluent are mostly due to population increases over the period. ${ }^{10}$ Phosphorus effluent increases by a maximum of 41 percent in the Patapsco and 11 percent in the Patuxent, again, due primarily to population change.

In Table 3, we compare the current plans scenario to the "no further treatment" or base case scenario. With increased population but higher levels of treatment under the current plans scenario, BOD and SS effluent levels are lower in all basins by the year 2000 compared to the base case. The current plans scenario results in large reductions in BOD and suspended solids in the Potomac, Patuxent, Susquehanna and Lower Bay. In fact, effluent levels are substantially lower than existing 1981 levels in these basins. However, the Patapsco is affected only slightly by the current plans scenario. Table 3 also shows that for phosphorus effluent, the northern basins of the Bay, the Potomac, Patuxent, and Patapsco, would see susbstantial reductions under current plans, while the Chester and Lower Bay would add no phosphorus removal capability.

It would be of interest to compare the two scenarios discussed above to successively higher, and uniform regulations. Existing regulations are uniform in the sense that all plants must achieve at least secondary treatment by a specified date, while other plants must treat beyond that level depending on water quality near the plant. Columns 4,5 and 6 of Table 3 show successively higher uniform levels of treatment for the various pollutants by the year 2000. For BOD, the base case scenario results are the same as they would be under uniform secondary treatment in the Patuxent and the Patapsco basins. The other basins show that a uniform requirement for a minimum of secondary treatment would reduce effluent. The current plans scenario can also be compared to the uniform treatment scenarios to see what level of treatment is implied under 
An Application to the Chesapeake Bay

Table 3

Percentage Changes in Annual Effluent by Year 2000 Over Base Case (1981)

\begin{tabular}{|c|c|c|c|c|c|c|c|c|}
\hline \multirow[b]{3}{*}{$\begin{array}{l}\text { River } \\
\text { Basins }\end{array}$} & \multirow[b]{3}{*}{$\begin{array}{c}\text { Effluent (1981) } \\
\text { thousand tons/ } \\
\text { Year }\end{array}$} & \multicolumn{7}{|c|}{ Percent Changes Over 1981 Base Effluent by Year 2000} \\
\hline & & \multirow[b]{2}{*}{$\begin{array}{l}\text { Base } \\
\text { Case }\end{array}$} & \multirow[b]{2}{*}{$\begin{array}{l}\text { Current } \\
\text { Plans }\end{array}$} & \multicolumn{3}{|c|}{ Minimum Treatment Levels of: } & \multirow[b]{2}{*}{$\begin{array}{l}\text { Population } \\
\text { Limitation }\end{array}$} & \multirow[b]{2}{*}{$\begin{array}{r}\text { Phosphorus } \\
\text { Ban }\end{array}$} \\
\hline & & & & Secondary & \multirow[t]{2}{*}{$\begin{array}{l}\text { Advanced } \\
\text { Secondary }\end{array}$} & $\begin{array}{c}\text { Advanced } \\
\text { Wastewater }\end{array}$ & & \\
\hline & & & & BOD & & & & \\
\hline Potomac & 6035 & 36.0 & -43.2 & 32.0 & 16.6 & -6.5 & 24.9 & \\
\hline Patuxent & 528 & 10.6 & -17.2 & 10.6 & -11.0 & -37.7 & 5.8 & \\
\hline Patapsco & 7467 & 25.6 & 22.7 & 25.6 & -27.4 & -61.6 & 11.5 & \\
\hline Chester & 100 & 27.0 & -1.0 & 18.0 & -25.0 & -36.0 & 14.5 & \\
\hline Eastern Shore & 512 & 21.1 & 3.7 & 14.6 & -26.0 & -36.9 & 12.1 & \\
\hline Susquehanna & 3604 & 11.1 & -17.1 & -2.4 & -40.4 & -62.7 & 7.1 & \\
\hline Lower Bay & 9733 & 18.0 & -42.1 & -41.5 & -65.8 & -89.5 & 11.3 & \\
\hline & & & & 18pended Sol & lids & & & \\
\hline Potomac & 6298 & 38.6 & -28.9 & 37.4 & 23.1 & -4.1 & 26.1 & \\
\hline Patuxent & 475 & 11.6 & -28.2 & 11.6 & -19.6 & -37.3 & 6.8 & \\
\hline Patapsco & 7985 & 25.4 & 21.3 & 25.4 & -48.3 & -66.6 & 11.7 & \\
\hline Chester & 104 & 32.7 & 27.9 & 67.3 & -57.7 & -72.1 & 19.7 & \\
\hline Eastern Shore & 608 & 23.4 & 3.3 & 21.7 & -43.3 & -44.1 & 13.4 & \\
\hline Susquehanna & 4229 & 12.8 & -8.5 & 1.3 & -33.5 & -67.1 & 8.3 & \\
\hline Lower Bay & 7341 & 21.1 & -31.6 & -30.7 & -59.2 & -85.7 & 7.9 & \\
\hline & & & & Phosphorus & & & & \\
\hline Potomac & 1458 & 25.2 & -40.7 & -36.6 & -44.3 & -87.0 & 15.2 & 6.5 \\
\hline Patuxent & 561 & 11.1 & -80.4 & 11.1 & -51.5 & -88.1 & 6.4 & -17.0 \\
\hline Patapsco & 1761 & 41.0 & -26.5 & 41.0 & -47.4 & -82.1 & 26.9 & 6.3 \\
\hline Chester & 43 & 25.6 & 25.6 & 25.6 & -72.1 & -90.7 & 13.1 & -6.0 \\
\hline Eastern Shore & 270 & 17.4 & 9.3 & 17.4 & -74.8 & -91.1 & 8.7 & -11.9 \\
\hline Susquehanna & 950 & 30.4 & -12.9 & -42.7 & -60.2 & -71.7 & 25.0 & -2.0 \\
\hline Lower Bay & 3048 & 29.8 & 29.8 & 29.8 & -72.3 & -90.6 & 5.0 & -2.7 \\
\hline
\end{tabular}

the current plans forecast. For BOD, current plans for the Potomac imply advanced wastewater treatment; for the Patuxent, just beyond advanced secondary treatment; for the Chester, Eastern Shore, Susquehanna and Lower Bay, between secondary and advanced secondary; and for the Patapsco, just under secondary.

Table 3 also displays the reduction in phosphorus under uniform and successively higher levels of treatment. Current plans for the Patuxent imply treatment capability close to the highest removal level, advanced wastewater treatment. For all other basins, current plans indicate treatment of phosphorus between secondary and advanced secondary, and less than secondary only in the Susquehanna.

Table 3 shows some additional scenarios. There is the possibility that population growth could be different than predicted, or actually limited by land-use restrictions as an alternative means of reducing effluent to the Bay. The Population Limitation columns of Table 3 show the resulting effluent when the population growth rate during the 1981-2000 period is held to one-half the forecast growth rate shown in Table 1. This reduces effluent by more than a minimum level of secondary treatment for BOD and suspended solids in all basins except in the Susquehanna and Lower Bay. For phosphorus removal, we can see that the reduced population growth rates do better than secondary treatment in the Patapsco and the Patuxent.

The Phosphorus Ban column of Table 3 shows the phosphorus effluent results compared with the base case if there were a ban on the use of phosphate detergents. The state of 
Table 4

Average Annual Costs

Capital + Operating and Maintenance

(Year 2000, Thousands of 1981 dollars)

\begin{tabular}{lrrrrrr}
\hline \hline & & \multicolumn{5}{c}{ \% Change From Base } \\
\cline { 3 - 7 } River Basin & Base Case & $\begin{array}{c}\text { Current } \\
\text { Plans }\end{array}$ & $\begin{array}{c}\text { Secondary } \\
\text { Treatment }\end{array}$ & AWT & $\begin{array}{c}\text { Secondary Treatment } \\
\text { Nutrient Removal }\end{array}$ & $\begin{array}{c}\text { AWT/ } \\
\text { Nutrient Removal }\end{array}$ \\
\hline Potomac & 35,280 & 64.0 & 2.9 & 25.9 & 17.8 & 193.4 \\
Patuxent & 6,555 & 81.7 & 9.2 & 30.9 & 21.1 & 154.2 \\
Patapsco & 13,921 & 12.4 & 0.0 & 40.8 & 14.3 & 315.8 \\
Chester & 1,221 & 59.9 & 18.4 & 100.8 & 89.1 & 127.1 \\
Eastern Shore & 4,602 & 40.6 & 10.6 & 83.0 & 70.8 & 154.6 \\
Susquehanna & 27,781 & 28.4 & 6.5 & 56.7 & 34.4 & 135.9 \\
Lower Bay & 21,646 & 19.4 & 17.3 & 50.8 & 39.4 & 191.2 \\
\hline \hline
\end{tabular}

Maryland is in the process of implementing such a ban, and the state of Virginia is considering one (Chesapeake Bay Commission, 1985), as a way of reducing phosphorus loadings in the Bay. ${ }^{11}$ The evidence shows that a phosphate detergent ban of the type being considered would reduce phosphorus influent by about 25 percent. In our model, this is equivalent to changing the influent coefficient for phosphorus, $\alpha_{\mathrm{ph}}$, as shown in equation (2). We assume that plants which treated phosphorus in 1981, under the base case scenario, would continue to treat phosphorus. The ban does better in terms of phosphorus removal than uniform secondary treatment in all basins except for the Potomac and the Susquehanna. The ban would also reduce more phosphorus than under the current plans scenario for the Chester, Eastern Shore and Lower Bay, since there was no phosphorus removal targeted for those basins.

Table 4 presents some of the costs of the various scenarios presented above. ${ }^{12}$ The costs include annualized capital and operating and maintenance costs of achieving the year 2000 level of treatment and population. It is the cost over what is in place, or existing, in 1981. Column one shows the dollar costs in thousands of 1981 dollars of providing the level of treatment in place at that time for the larger populations by the year 2000 . The annualized costs are between $\$ 1$ million and $\$ 35$ million for the Chester and Potomac basins respectively. The largest percentage changes under the current plans scenario are for the Patuxent (81.7 percent) and the Potomac (64 percent). The Patuxent basin would, under current plans, be gaining a high level of phosphorus removal capability.
The Potomac would be gaining high levels of removal of all three pollutants. The remaining columns of Table 4 show selected costs for the uniform treatment scenarios.

Table 5 shows the average cost of pollutant removal under successively higher levels of removal for BOD and phosphorus. ${ }^{13}$ For each basin, we display the additional annual cost per kilogram removed over the base case. ${ }^{14}$ For $B O D$, average annual costs of removal vary across basins from less than $\$ 1 /$ kilogram in the Lower Bay and the Patapsco to more than \$20/ kilogram in the Chester. Under the current plans scenario, the smallest additions to BOD removal occur in the Patapsco, which is one of the lowest cost basins. Surprisingly, the average costs of additional removal are not increasing for all basins. They are decreasing or have decreased in sections for the Potomac, Patuxent, Eastern Shore and Chester. This is contrary to most evidence on the marginal costs of additional removal capacity. ${ }^{16}$.

The average cost of phosphorus removal also varies substantially across basins, and is higher than for BOD removal. Average costs are increasing at higher levels of removal for all basins. The lowest cost basins are the Lower Bay, the Patapsco and the Patuxent. The Susquehanna has the highest average cost of phosphorus removal and the Potomac has the highest (and most steeply rising) cost for the more advanced treatment levels. For management of POTWs around the Bay, we would need to combine regional estimates of the marginal cost of effluent removal with measurements of water quality. Here river basins are the regions, so we can look at water quality in the Bay itself as affected by the 
Table 5

Average Cost of Effluent Removal

(\$/kilogram removed)

Year 2000

\begin{tabular}{lccc}
\hline & \multicolumn{3}{c}{ Changes Over Base Case } \\
\cline { 2 - 5 } River Basin & Secondary & Advanced Secondary & $\begin{array}{c}\text { Advanced Wastewater } \\
\text { Treatment }\end{array}$ \\
\hline & \multicolumn{4}{c}{ BOD } \\
Potomac & 4.20 & 4.30 & 3.60 \\
Patuxent & - & 9.80 & 7.90 \\
Patapsco & - & .44 & .87 \\
Chester & 25.00 & 19.50 & 13.70 \\
Eastern Shore & 14.80 & 11.40 & 12.90 \\
Susquehanna & 3.70 & 5.80 & 5.90 \\
Lower Bay & .65 & .79 & 1.05
\end{tabular}

\begin{tabular}{lccc}
\multicolumn{2}{c}{ Phosphorus } & 41.73 \\
Potomac & 6.98 & 9.99 & 18.18 \\
Patuxent & - & 6.56 & 20.28 \\
Patapsco & - & 3.49 & 31.04 \\
Chester & - & 28.57 & 24.28 \\
Eastern Shore & - & 18.48 & 38.92 \\
Susquehanna & 13.75 & 21.39 & 11.27 \\
Lower Bay & - & 3.75 & \\
\hline
\end{tabular}

separate river basins. The two areas of the Bay which have the greatest nutrient problems are the northern basins and the Lower Bay. Of the four northern basins of the Bay, which include the Potomac, the Patuxent, the Patapsco and the Susquehanna, those with the lowest phosphorus reduction costs are the Patuxent and the Patapsco. ${ }^{16}$ Under the current plans scenario, showing treatment capability to the year 2000, high levels of phosphorus removal are proposed for the Patuxent, but not the Patapsco or the Lower Bay. There is some indication, then, that additional phosphorus removal should be undertaken in these two regions. The costs of removing phosphorus through POWTs should be weighed against the costs of non-point source phosphorus removal for all basins.

\section{Summary}

We have presented a model for forecasting regional effluent and associated costs from publicly owned sewage treatment works. We have shown how the various components of population growth affect net pollutant effluent. Changes in treatment efficiencies can have a large effect on effluent, especially when treatment levels are high.

We applied the model to seven river basins of the Chesapeake Bay for three pollutants: BOD, suspended solids, and phosphorus. We have shown what effluent levels would be with no additional treatment capability by the year 2000 , and have compared them to a number of other possible scenarios. We find that existing regulations or "current plans " for the year 2000 , would reduce pollutant effluent levels in many cases below the 1981 level. Also, current plans imply quite different levels of treatment for the different basins in the Bay. We also find that the average cost of removing successively higher levels of effluent varies substantially across basins. The lower Bay and the northern basins contribute most to nutrient pollution in the Bay. Among these basins, the average cost of additional treatment is high in the Potomac and the Susquehanna, and lower in the Paturent, Patapsco and Lower Bay. These costs, combined with water quality data and estimates of the cost alternative methods of reducing pollution, can guide Bay managment of POTW treatment technology in the future.

The average treatment cost data derived to date suggest that opportunities exist for improving the overall efficiency of sewage treat- 
ment for the total Chesapeake Bay system. However, the design of our optimal management plan for the entire system requires the derivation of marginal cost data which will require further investigation.

\section{FOOTNOTES}

'See Chesapeake Bay: A Framework for Action, U.S. Environmental Protection Agency, 1983, p. xv.

${ }^{2} \mathrm{BOD}$ is Biological Oxygen Demand. BOD and susspended solids are the conventional measures of water pollution from degradable organic sources.

${ }^{3}$ Currently, it is estimated that 60 percent of phosphorus in the Bay comes from point sources such as POTWs. (See Chesapeake Bay: A Framework for Action, 1983, p. 42.)

'Most phosphorus effluent comes from residential waste rather than industrial waste. (See Chesapeake Bay: A Framework for Action, 1983, p. 49.)

'In the application that follows, we use a given set of population forecasts for the Chesapeake Bay region since we are less concerned with the population forecasts than we are with the POTW treatment of pollution. Different population forecasts could easily be used.

'These coefficients may vary by basin because of soil conditions, age of sewage systems, rainfall, etc.

${ }^{7}$ The river basin population forecasts are an aggregate of county level forecasts for the Chesapeake Bay region.

'In a mass balance context, septic waste systems may also contribute to pollution in the Bay. When those systems are not working efficiently, they will add to nonpoint sources of pollution.

'Other nutrients found in POTW effluent are nitrogen compounds. Nitrogen effluent is not forecast here because the data available from the Needs Survey and other sources were inadequate.

${ }^{10}$ There is a further effect of population on treatment efficiencies in this model. Population changes affect the flows at each plant, which affect the flow-weighted treatment efficiencies. These effects on treatment efficiencies are the reason for differences in percentage change in population and effluent for this scenario.

"A better method for reducing use of phosphate detergents would be to tax their use. Given some elasticity of demand for this type of detergent, use would be reduced. Either approach, the ban or a tax, would enter this model in the same way.

${ }^{12}$ We do not attempt to estimate the costs of the phosphorus ban or the population limitation scenarios here.

${ }^{13} \mathrm{We}$ do not compare our cost for current plans since that scenario is a combination of conventional pollutant removal and nutrient removal. It would be difficult to attribute costs to the different pollutants.

${ }^{14}$ These are average costs, not marginal costs. We have another study which derives and estimates marginal costs of effluent removal from POTWs (McConnell, et al., 1985).

${ }^{16}$ See Fraas and Munley, 1984.

${ }^{10}$ Marginal costs of phosphorus removal are also lowest in the Patuxent and the Patapsco of the northern river basins.

\section{REFERENCES}

Fraas, Arthur G., and Vincent Munley. "Municipal Wastewater Treatment Costs." Joumal of Environmental Economics and Management, Vol. II, March 1984.

"Federal Register." U.S. Government Printing Office, Vol. 49, No. 184.

Harris, Curtis C., Jr., "New Development and Extension of the Multiregional Multi-Industry Forecasting Model." Joumal of Regional Science, Vol. 20, November 2, 1980.

McConnell, Virginia, John H. Cumberland and Patrice Gordon. "Regional Marginal Cost Functions for Municipal Water Treatment." BBER Working Paper, University of Maryland, 1985.

"Report on the Costs and Benefits of a Phosphate Detergent Ban." State of Virginia, Senate Document No. 9, prepared by Chesapeake Bay Commission, Virginia, 1985.

Tihansky, Dennis P. "Historical Development of Water Pollution Control Cost Functions." Joumal of Water Pollution Control Federation, Vol. 46, No. 5, May 1974.

U.S. E.P.A. Chesapeake Bay Program, Chesapeake Bay: A Framework for Action, and Appendices. Annapolis, Maryland. September 1983.

U.S. E.P.A. “1982 Needs Survey, Conveyance and Treatment of Municipal Wastewater." Washington, D.C., 1982.

U.S. E.P.A. Office of Water Programs Operations. "Operations and Maintenance Costs for Municipal Wastewater Facilities," Technical Report, Washington, D.C., 1981.

U.S. E.P.A. Office of Water Program Operations, Priorities and Needs Assessment Branch. "1982 Needs Survey, Technical Policy and Procedures," Categories i-v, 1982.

U.S. G.A.O. "Better Planning Can Reduce Size of Wastewater Treatment Facilities, Saving Millions in Construction Costs," 1982. 


\section{An Application to the Chesapeake Bay}

Appendix I

Cost Functions for POTWs (in millions of dollars)

\section{Capital Costs}

Primary: $\quad \mathrm{C}_{\mathrm{c}}=.69 \mathrm{~K}^{1.03}$

Secondary: $\quad \mathrm{C}_{\mathrm{c}}=2.96 \mathrm{~K}^{.7}$

Advanced Secondary: $\mathrm{C}_{\mathrm{c}}=3.34 \mathrm{~K}^{.69}$

Advanced Waste

Water Treatment: $\mathrm{C}_{\mathrm{c}}=3.73 \mathrm{~K}^{.7}$

with NR: $C_{c}=3.54 \mathrm{~K}^{.7}$
with NR: $C_{c}=4.01 \mathrm{~K}^{.68}$
with NR: $C_{c}=4.27 \mathrm{~K}^{.87}$

where $\mathrm{K}=$ domestic design flow or plant capacity.

Operating and Maintenance Costs

$\mathrm{C}_{o}=.103 \mathrm{~K}^{.776}$

Sources

U.S. Environmental Protection Agency, 1981 and 1982.

Appendix II

OLS Estimates of Gross Residual Coefficients (kilograms per person per day)(a)

\begin{tabular}{|c|c|c|c|c|c|c|c|c|}
\hline & & Potomac & Patuxent & Patapsco & Chester & $\begin{array}{c}\text { Eastern } \\
\text { Shore }\end{array}$ & Susquehanna & $\begin{array}{c}\text { Lower } \\
\text { Bay }\end{array}$ \\
\hline \multirow[t]{3}{*}{ BOD } & $\alpha$ & $\begin{array}{l}.0734 \\
(126 .)\end{array}$ & $\begin{array}{r}.0680 \\
(50 .)\end{array}$ & $\begin{array}{l}.0937 \\
(64 .)\end{array}$ & $\begin{array}{l}.1049 \\
(171 .)\end{array}$ & $\begin{array}{l}.0948 \\
(42 .)\end{array}$ & $\begin{array}{l}.0878 \\
(52 .)\end{array}$ & $\begin{array}{l}.0719 \\
(90 .)\end{array}$ \\
\hline & $\beta$ & $\begin{array}{l}.0630 \\
(246 .)\end{array}$ & $\begin{array}{l}.0149 \\
(.810)\end{array}$ & $-(b)$ & $\begin{array}{l}.0223 \\
(4.3)\end{array}$ & $\begin{array}{l}.0260 \\
(71 .)\end{array}$ & $\begin{array}{l}.0126 \\
(1.03)\end{array}$ & $\begin{array}{l}.0076 \\
(2.32)\end{array}$ \\
\hline & $R^{2}$ (adj) & .997 & .919 & .948 & .992 & .993 & .916 & .973 \\
\hline \multirow[t]{3}{*}{$\begin{array}{l}\text { Suspended } \\
\text { Solids }\end{array}$} & $\alpha$ & $\begin{array}{r}.0771 \\
(79 .)\end{array}$ & $\begin{array}{r}.06123 \\
(36 .)\end{array}$ & $\begin{array}{l}.0867 \\
(63 .)\end{array}$ & $\begin{array}{l}.1053 \\
(158 .)\end{array}$ & $\begin{array}{l}.1022 \\
(47 .)\end{array}$ & $\begin{array}{l}.0920 \\
(54 .)\end{array}$ & $\begin{array}{l}.0627 \\
(85 .)\end{array}$ \\
\hline & $\beta$ & $\begin{array}{l}.0689 \\
(161 .)\end{array}$ & $\begin{array}{r}.0148 \\
(64 .)\end{array}$ & $-(b)$ & $\begin{array}{l}.0222 \\
(4 .)\end{array}$ & $\begin{array}{l}.0228 \\
(65 .)\end{array}$ & $\begin{array}{l}.0098 \\
(.79)\end{array}$ & $\begin{array}{l}.0069 \\
(2.29)\end{array}$ \\
\hline & $R^{2}$ (adj) & .992 & .854 & .947 & .991 & .994 & .923 & .970 \\
\hline
\end{tabular}

OLS Estimates for Entire Chesapeake Bay Sample of POTWs

\begin{tabular}{cccc} 
& BOD & Suspended Solids & Phosphorus $^{\text {(c) }}$ \\
\hline$\alpha$ & .0745 & .0781 & .0061 \\
& \multicolumn{1}{c}{$(84.4)$} & $(63)$. & $(14.7)$ \\
& .0625 & .0684 & .0016 \\
$\mathrm{R}^{2}$ (adj) & $(160)$. & $(126)$. & $(7.17)$ \\
\hline \hline
\end{tabular}

NOTE: $\mathrm{t}$ - ratios are given in parenthesis below parameter estimates.

(a) Where the data allow, F-tests indicate that the coefficients should be estimated by river basin.

(b) There were no observations in the Patapsco basin for non-residents served. Where necessary bay-wide estimates were employed.

(c) Insasmuch as data on phosphorus were limited, estimates of bay-wide coefficients were employed. 


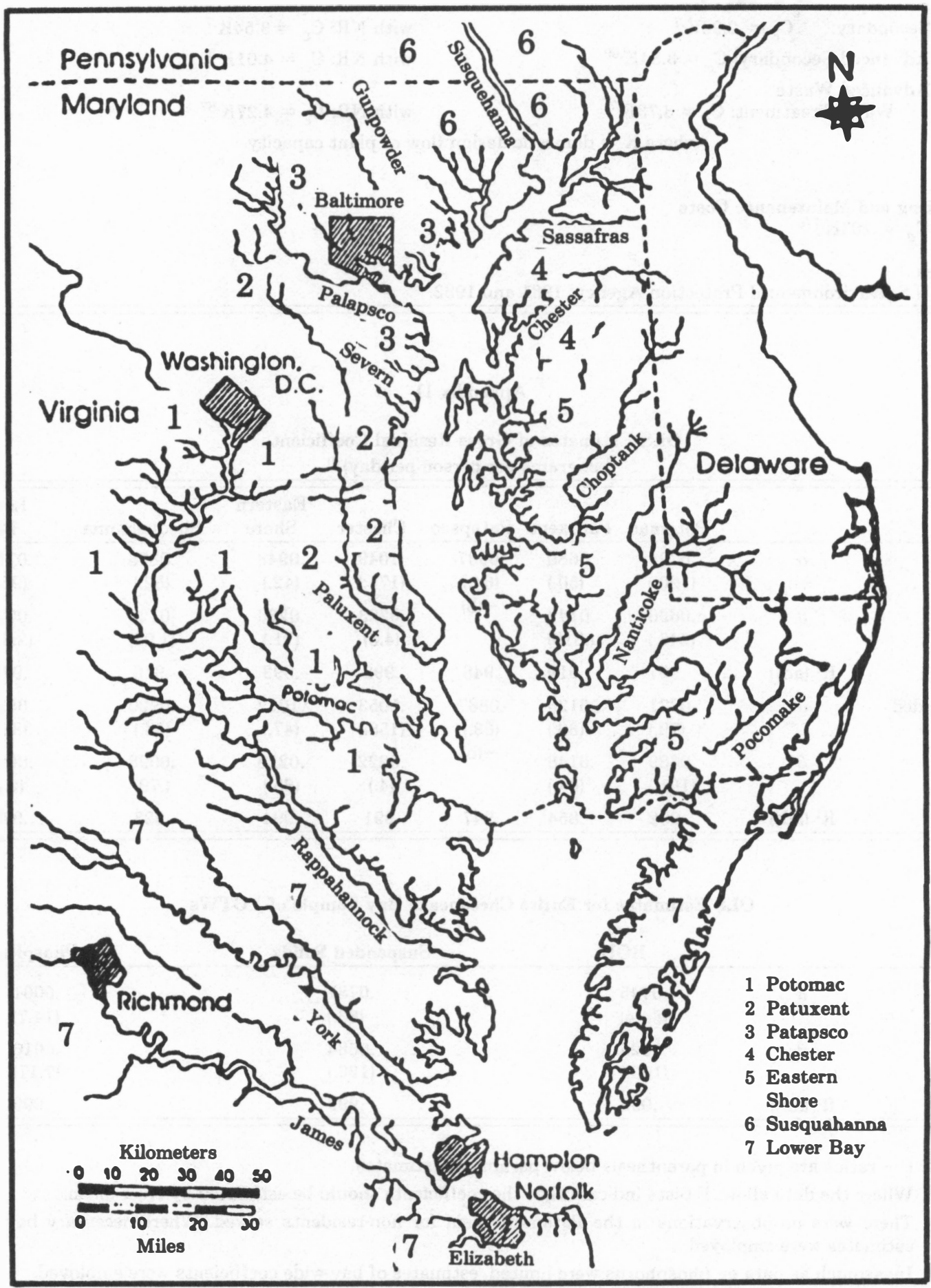

